\title{
A STUDY OF L2 LEARNERS' METAPHORICAL COMPETENCE AND PERSONALITY TYPES: A CASE OF THINKING/FEELING VS. JUDGING/PERCEIVING PERSONALITY CATEGORIES
}

\author{
Mahmood Hashemian \\ English Department, Faculty of Letters and Humanities, Shahrekord University, Iran \\ E-mail: hashemin-m@sku.ac.ir
}

\begin{abstract}
APA Citation: Hashemian, M. (2018). A study of L2 learners' metaphorical competence and personality types: A case of thinking/feeling vs. judging/perceiving personality categories. Indonesian Journal of Learning and Instruction, 1(2), 21-32.
\end{abstract}

Received: 17-06-2018

Accepted: 23-08-2018

Published: 01-10-2018

\begin{abstract}
This study explores the (possible) relationship between affective variables and metaphorical competence. The main objective is to investigate the difference between the thinking/feeling and the judging/perceiving personality variables and L2 learners' metaphorical competence. Participants are 90 male and female Iranian L2 learners who take the OPT and responded to the Myers Briggs Type Indicator (MBTI) personality questionnaire. They are divided into 2 categories of thinking/feeling and judging/perceiving in line with the results of the MBTI. Then, a teacher-made metaphor test is administered to the groups to check their metaphorical competence. Finally, to observe whether there is any significant difference between the 2 groups in terms of metaphor comprehension, an independent samples $t$ test is carried out. The metaphor test is the dependent variable and the personality type is the independent variable. Results show that the thinking/feeling personality category has no significant effect on the participants' metaphorical competence, whereas the judging/perceiving personality category play some role in their metaphorical competence in that the perceiving participants outperformed the judging ones on the metaphor test.
\end{abstract}

Keywords: metaphorical competence; personality type; myers briggs type indicator (MBTI); thinking/feeling; judging/perceiving.

\section{INTRODUCTION}

Metaphor is at the very heart of mind and language, and it has been such a mindboggling concern since the time of Aristotle (Tendahl \& Gibbs, 2008). Being a widespread feature of everyday thought and language (Feldman, 2006; Lakoff, in press; Lakoff \& Johnson, 1999), metaphor has attracted the attention of both L2 teachers and learners as a teaching device (Ortony, 1975; Sacristan, 2004). Sacristan (2004) believed that by using metaphors in L2 teaching programs, L2 learners are provided with an appropriate device raising their awareness and knowledge of the main issues, concepts, and models to an acceptable level. Metaphor and metaphorical thinking increase our understanding by relating one thing to another kind of thing (Azuma, 2005), and this kind of connection leads to successful metaphor comprehension and production that is the basis for the key concept of metaphorical competence in learning an L2 (Littlemore \& Low, 2006). Metaphorical competence is defined as the natural ability to comprehend and use metaphors in a given language. Lack of knowledge about metaphorical concepts leads to the wrong transfer of L1 metaphorical expressions similar to their L2 counterparts. Therefore, it is necessary for L2 teachers to make their learners aware of the L2 conceptual system (Hashemian \& Talebinezhad, 2007).

There are numerous factors affecting successful L2 learning, such as intelligence 


\section{Mahmood Hashemian}

A study of L2 learners' metaphorical competence and personality types: A case of thinking/feeling vs. judging/perceiving personality categories

(Binet, 1905; Gardner, 1983), aptitude (Teepen, 2005), motivation and attitude (Crookes \& Schmidt, 1991), learner preferences (Reid, 1987), learner beliefs (Tittle, 2000), age (Flege, Yeni-Komshian, \& Liu, 1999), and personality (Eysenck, 1997). Learning more about the students and gaining some information about the personal differences in the language classroom have always been one of the primary objectives in L2 learning and teaching. Selecting an appropriate method to apply to the teachinglearning process has been the great concern of teachers in the history of language teaching. However, in modern language teaching today, involving with the students' profiles individually on academic basis and trying to learn more about them help L2 learners and teachers more to reach the objectives of the program (Erton, 2010). Here, the personality of the student appears to be in the core of the issue. Personality is defined as a broad term related to general behavioral patterns individuals manifest in their everyday lives (Balkis \& Isiker, 2005). A number of personality characteristics have been proposed as likely to affect L2 learning, measured by different personality inventories proposed by a number of researchers (Eysenck \& Eysenck, 1964; Holland, 1973; Myers \& Myers, 1980). Myers Briggs Type Indicator (MBTI) is one of those inventories of personality assessment based on the four categories of human personality, each of which consists of two opposite preferences that determine the way we function in all situations (Pittenger, 1993). The four dimensions of human personality, according to the MBTI scale, are: extroversion (E) vs. introversion (I), sensing (S) vs. intuition (N), thinking (T) vs. feeling $(\mathrm{F})$, and judgment $(\mathrm{J})$ vs. perception (P).

As expressed by Wilz (2000), our personality also affects the way we learn. So, an understanding of personality type would be useful in defining why we learn differently. Each human being is unique and has unique preferences. Identifying these unique preferences and the different behavior patterns of each individual improves our understanding of ourselves and of the world around us (Marefat, 2006). Many studies had been conducted in this regard which investigated the effects of different categories of personality types on different aspects of academic success and performance (e.g., Balkis \& Isiker, 2005; Erton, 2010).

Despite great strides made on metaphor (Danesi, 1994, 1995), metaphorical competence (Hashemian, 2007), and personality types (Eysenck, 1997) in recent years, the reams of research papers on L2 learning published up to now attest to the fact that, to the best of our current knowledge, almost nothing has been done on the relationship between L2 learners' personality types and metaphorical competence. The present study set out to find out the (possible) relationship between L2 learners' personality types and their metaphorical competence in order to fill the existing gap.

Metaphor and metaphorical competence have dominated discussions of SLA researchers since the late $20^{\text {th }}$ century (Azuma, 2005; Danesi, 1992; Hashemian \& Talebinezhad, 2007; Littlemore \& Low, 2006). Despite its widespread use and need in everyday life, metaphor is most of the time neglected by L2 teachers. Because of lack of experiments on language learning and discourse programming, the inclusion of metaphorical competence in L2 learning and teaching programs has not yet that much penetrated the mindset of researchers and practitioners (Danesi, 1995). The works of Lakoff and Johnson in linguistics (e.g., Lakoff, 1987; Johnson, 1987; Lakoff \& Johnson, 1980) might have been the most relevant to developing the notion of metaphorical competence for L2 teaching during the past decades. The crucial claim made by these two scholars is that our most common concepts are forged via metaphor (Danesi, 1995). Lakoff and Johnson in their seminal work in 1980 emphasized the omnipresent role of metaphorical schema in everyday life and made it the case of their 
future educational investigation. Metaphor is not something that occurs only in literary uses despite the widespread fallacy believed by many, but it is also the omnipresent part of all other kinds of discourse-professional or nonprofessional (Donglin \& Yin, 2009).

In this regard, Hashemian and Talebinezhad (2007) proposed the idea of metaphorical competence as the natural ability to comprehend and use metaphors in a given language. Metaphorical competence, like linguistic competence, is a good tool to measure L2 learners' proficiency and tap into their existing L2 mastery, and because of its vital role in L2 proficiency and comprehension, it is under great controversy (Yan, 2007).

For many years, people have debated about different personality types and their indispensable role and effect on every aspect of life. Personality is defined as a set of thoughts, feelings, and behaviors that characterize an individual and are stable over time (Racicot, Venne, Durivage, \& Vaillancourt, 2011). This stability would affect every aspect of a person's life, one of which is his or her metaphorical competence.

Much work has been done on the relationship between personality types and many other factors related to SLA, such as learning styles (Honey \& Mumford, 1992) and strategies (Brown, 2000), but to the best of our present knowledge, despite its prevalent use and function in everyday language, nothing has been done on the relationship between metaphorical competence and personality types.

Lawrence (1984) mixed the learning style research with MBTI. He believes that MBTI can be used to develop teaching methods to meet the needs of different types. Smith, Irey, and McCaulley (1973) found that personality types can influence L2 learners' attitude and performance in selfpaced instruction. They consider this as the major cause of failure in college teaching that stems from L2 teachers and learners' lack of recognition of each other's differences. This major realm of differences gave rise to the need for different learning activities. Smith et al. (1973) believe that by assigning appropriate instructional modules and packages to fit different styles of learner perception and judgment, the outcome of self-paced instruction and also learning will be raised. Very broadly, the thinking behind the current research is to investigate the differences, if any, between the thinking/feeling and judging/perceiving personality types identified by MBTI in terms of metaphorical competence. Afterward, based upon the abovementioned deliberations, the following questions stand out:

1. Is there any significant difference between feeling and thinking personality types in terms of metaphorical competence?

2. Is there any significant difference between perceiving and judging personality types in terms of metaphorical competence?

Also, in line with the abovementioned research questions, the following null hypotheses are formulated:

$\mathrm{H}_{01}$ : There is no significant difference between feeling and thinking personality types in terms of metaphorical competence scores.

$\mathrm{H}_{02}$ : There is no significant difference between perceiving and judging personality types in terms of metaphorical competence scores.

\section{METHOD}

For the present study, the participants were elected from one English Literature class and one Translation of Idiomatic Expressions class, each having 45 male and female junior learners majoring in English Translation, aged 20-26, all from Shahrekord University, Iran. In order to ensure the homogeneity of the participants, the Oxford Placement Test (OPT) was administered to the participants in the first stage of the study, from which the participants whose scores were lower than the mean score of the total possible scores were excluded from the study. 


\section{Mahmood Hashemian}

A study of L2 learners' metaphorical competence and personality types: A case of thinking/feeling vs. judging/perceiving personality categories

The OPT was administered to the participants in the first stage of the study in order to determine their proficiency level and also to ensure the homogeneity of the participants under investigation.

The MBTI was used in order to assess the personality types of the participants and to examine the influence of these personality types on the participants' metaphorical competence.

Also, a teacher-made metaphor test was administered to the participants in order to test the metaphorical knowledge. It was designed based on the books Idiom Organiser (Wright, 1999) and 136 American Idioms (Collis, 2004). It should be added that the reliability and validity of the test was examined via the experts' views and Cronbach's Alpha. It is well worth mentioning that the calculated reliability coefficient for the aforementioned test was .74 .

After selecting the participants randomly from Shahrekord University, the OPT was administered to them to determine their proficiency level and to ensure their homogeneity. Among the participants who took the test, only those whose scores were above the mean were selected as the sample for the study. Then, a teacher-made metaphor test was conducted to tap into the participants' metaphorical competence. The last stage was to identify the participants' personality types by MBTI during the semester.

The data collected (i.e., the scores on the English metaphor test and MBTI) were subjected to both descriptive statistics and inferential statistics. As for the former, such descriptive statistics techniques as standard deviation and mean were calculated. As for the latter, using SPSS, an independent samples $t$ tests was run to compare each of the preferences of the two dichotomies of feeling/thinking and judging/perceiving in terms of metaphorical competence, and to see if there was any significant difference between them in terms of metaphorical competence.

\section{RESULTS AND DISCUSSION \\ Descriptive results for feeling/thinking and perceiving/judging preferences}

In this section of the $t$ test analysis, the answer of whether there was a statistical strong relationship between feeling/thinking and judging/perceiving personality type and the metaphorical competence of the participants was examined through statistical methods.

Table 2. Descriptive statistics of the feeling/thinking and judging/perceiving participants

\begin{tabular}{|c|c|c|c|c|c|c|c|c|c|}
\hline & & \multirow[t]{2}{*}{ Min } & \multirow[t]{2}{*}{ Max } & \multirow{2}{*}{$\begin{array}{c}\text { Mean } \\
\text { Statistic }\end{array}$} & \multirow{2}{*}{$\begin{array}{c}\text { Std. } \\
\text { Dev. } \\
\text { Statistic }\end{array}$} & \multicolumn{2}{|c|}{ Skewness } & \multicolumn{2}{|c|}{ Kurtosis } \\
\hline & & & & & & Statistic & $\begin{array}{c}\text { Std. } \\
\text { Error }\end{array}$ & Statistic & $\begin{array}{c}\text { Std. } \\
\text { Error }\end{array}$ \\
\hline $\begin{array}{l}\text { Metaphorical } \\
\text { Competence of the } \\
\text { Feeling }\end{array}$ & 42 & 14 & 19.50 & 17.03 & 1.45 & -.34 & .36 & -.31 & .71 \\
\hline $\begin{array}{l}\text { Metaphorical } \\
\text { Competence of the } \\
\text { Thinking }\end{array}$ & 48 & 16 & 19 & 17.37 & .91 & .04 & .34 & -1.06 & .37 \\
\hline $\begin{array}{l}\text { Metaphorical } \\
\text { Competence of the } \\
\text { Perceiving }\end{array}$ & 54 & 14 & 18.75 & 16.97 & 1.25 & -.65 & .32 & -.95 & .63 \\
\hline $\begin{array}{l}\text { Metaphorical } \\
\text { Competence of the } \\
\text { Judging }\end{array}$ & 36 & 16.50 & 19.50 & 17.58 & 1.03 & .44 & .39 & -1.11 & .76 \\
\hline
\end{tabular}

According to the descriptive statistics, the mean score of the metaphorical competence of the feeling participants was 17.03 and that of the thinking participants 
was 17.37 . Although statistically significant, the actual difference in the two mean scores was small, almost less than 1 scale point. The mean score of the metaphorical competence of the perceiving participants was 16.97 and that of the judging participants was 17.58. Although statistically significant, the actual difference in the two mean scores was small, but almost 1 scale point.

According to Kinnear and Gray (1999), the skewness and kurtosis values within the range of -1.5 to +1.5 indicate an acceptable normality of variances. According to Table 2 , the kurtosis and skewness statistics of metaphorical scores of the participants were within the range, suggesting the possibility of significant normality.

Figure 1 also shows the histogram of the metaphor scores of the feeling participants. According to the figure, the sample of the metaphor scores of the feeling did not have skewed scores. Also, the metaphor scores of the thinking looked more normal (see Figure 2).

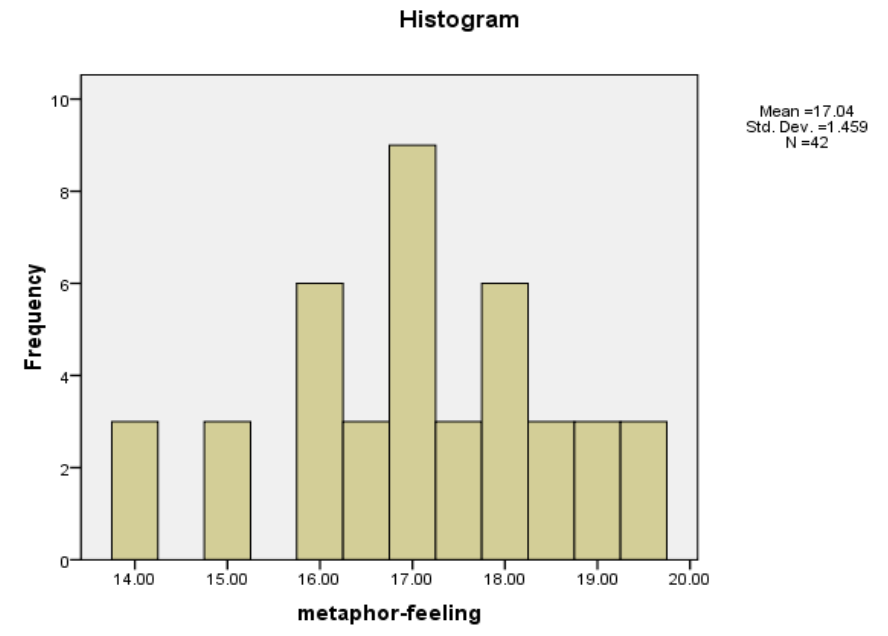

Figure 1. Metaphor scores of the feeling participants

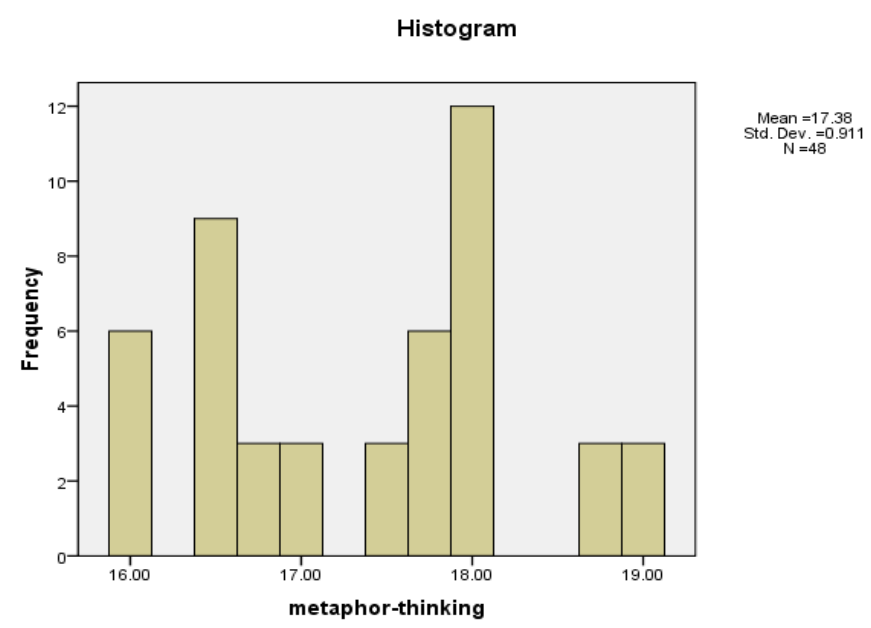

Figure 2. Metaphor scores of the thinking participants

Figures 3 and 4 showed the histograms of the metaphor scores of the judging and perceiving participants. According to the figures, the sample of the perceiving participants' scores seems to be skewed to the left (see Figure 3). However, its degree was not very great. Also, the histogram of the metaphor scores of the judging 


\section{Mahmood Hashemian}

A study of L2 learners' metaphorical competence and personality types: A case of thinking/feeling vs. judging/perceiving personality categories

participants seems to be a bit peaked (see Figure 4).

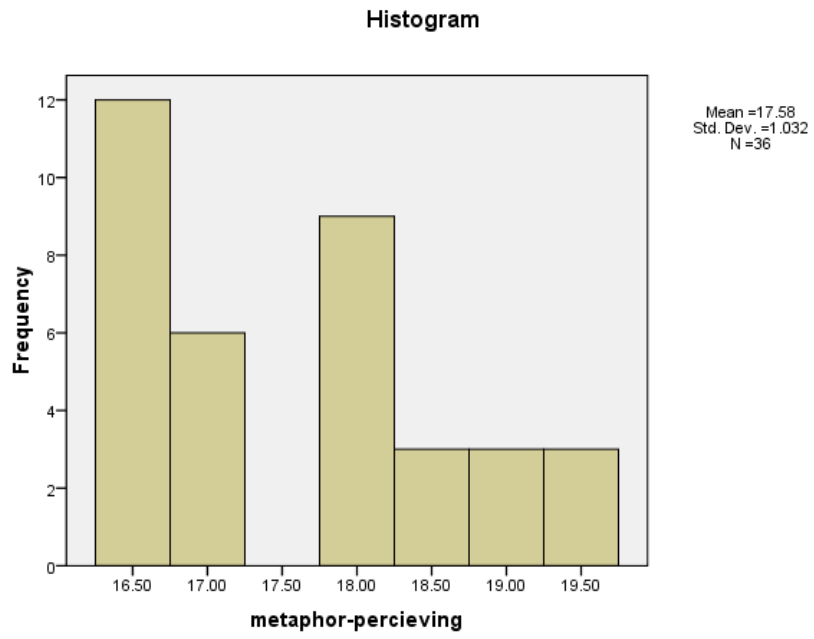

Figure 3. Metaphor scores of the perceiving participants.

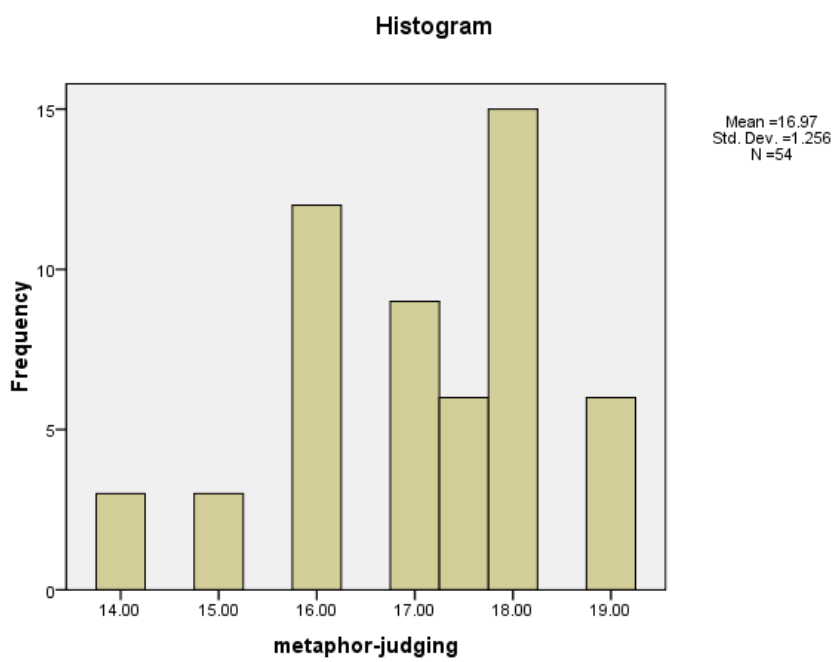

Figure 4. Metaphor scores of the judging participants.

Inferential results for feeling/thinking and To answer the research questions of the perceiving/judging preferences current study, independent samples $t$ tests were conducted (see Table 3 ).

Table 3. Independent samples t-test

\begin{tabular}{|c|c|c|c|c|c|c|c|c|}
\hline & & \multicolumn{2}{|c|}{$\begin{array}{l}\text { Levene's Test } \\
\text { for Equality } \\
\text { of Variances }\end{array}$} & \multicolumn{5}{|c|}{$t$ Test for Equality of Means } \\
\hline & & $F$ & Sig. & $t$ & $D f$ & $\begin{array}{c}\text { Sig. } \\
\text { (2-tailed) }\end{array}$ & $\begin{array}{c}\text { Mean } \\
\text { Difference }\end{array}$ & $\begin{array}{c}\text { Std. Error } \\
\text { Differenc } \\
\mathrm{e} \\
\end{array}$ \\
\hline $\begin{array}{l}\text { Metaphor } \\
\text { Feeling }\end{array}$ & $\begin{array}{l}\text { Equal } \\
\text { Variances }\end{array}$ & 6.000 & .016 & $\begin{array}{c}- \\
1.340\end{array}$ & 88 & .184 & -.33929 & .25315 \\
\hline
\end{tabular}




\begin{tabular}{|c|c|c|c|c|c|c|}
\hline & Assumed & & & & & \\
\hline Metaphor & Equal & - & 66.934 & .198 & -.33929 & .26076 \\
\hline \multirow[t]{3}{*}{ Thinking } & Variances & 1.301 & & & & \\
\hline & Not & & & & & \\
\hline & $\begin{array}{l}\text { Assumed } \\
\text { Egual }\end{array}$ & & 88 & & 61 & 25 \\
\hline \multirow{2}{*}{ Perceiving } & Variances & & & & & \\
\hline & Assumed & & & & & \\
\hline Metaphor & Equal & & 84.1 & & .61 & .24 \\
\hline \multirow[t]{3}{*}{ Judging } & Variances & & & & & \\
\hline & Not & & & & & \\
\hline & Assumed & & & & & \\
\hline
\end{tabular}

The results of the $t$ test indicated the inequality of the variances of the differences in the mean scores $(p=.01)$. According to Table 3, equal variances were not assumed for the $t$ test, and there was no significant difference in the scores of the feeling ( $M=$ 17.03, $S D=1.45)$ and the thinking $(M=$ $17.37, S D=.91) ; t(66.93)=-1.3, p=.19$ (two-tailed). The magnitude of the differences in the means (mean difference $=$ $-.33,95 \% \mathrm{CI}:-.85$ to .18$)$ was very small (eta squared $=.01$ ). Thus, the first null hypothesis is in line with our expectations and is not rejected.

Also, Table 3 demonstrates the inequality of the variances of the differences in the mean scores $(p=.39)$. This inequality showed that the equal variances were not assumed for the $t$ test. According to Table 2, there was a significant difference in the scores of the perceiving $(M=17.58, S D=$ 1.03) and the judging $(M=16.97, S D=$ $1.25) ; t(84.1)=2.52, p=.01$ (two-tailed). The magnitude of the differences in the means (mean difference $=.6,95 \%$ CI: .1 to 1.09) was moderate (eta squared $=.06$ ), which was just like that of the first category-introversion/extroversion - and it showed that $6 \%$ of the participants' metaphorical competence was explained by perceiving. Thus, the second null hypothesis was rejected, and the following directional hypothesis comes forth:

$\mathrm{H}_{3}$ : There was a significant difference between perceiving and judging personality types in terms of metaphorical competence scores.
Being one of the most important concepts of L2 pedagogy, metaphor had been studied by a large number of scholars (Feldman, 2006; Gibbs, 2006; Lakoff, in press; Tendahl \& Gibbs, 2008) in order to define and fill the existing gap which had been felt about the status of metaphor and the uncertainty and doubts which had been felt to exist between the traditional and contemporary views of metaphor.

Most scholars had unanimously agreed upon what Lakoff and Johnson (1980) proposed about the naturality of our metaphorical conceptual system, which manifests itself in linguistic evidence and everyday verbal or written communication.

Attempts had been made to define and relate this natural and ubiquitous metaphorical competence to different attributes of learners, such as cognitive styles (Fadaei, 2011), emotional intelligence (Forouzandeh, 2012), and so on, but to the best of our knowledge, nothing had been done on the most effective and most dominant feature of every human being, that is, his or her personality trait, and its roled on a better understanding L2 learners' metaphorical competence.

One of the important factors which leaded to the prevalent development of a country was improving the quality of education in that country and to invest on its educational and human resources. One of the main objectives of this qualified education was the improvement of students' academic achievement which helped them actualize their talents and abilities (Hakimi, Hejazi, \& Lavasani, 2011). In their seminal work in 


\section{Mahmood Hashemian}

A study of L2 learners' metaphorical competence and personality types: A case of thinking/feeling vs. judging/perceiving personality categories

2005, Caspi, Robert, and Shiner investigated educational settings such as schools in which personality traits and academic achievement of students were related. They concluded that the relationship between personality and academic achievement was something personal, that was, people choose situations to which they feel more comfortable. When this happens and achievement criteria and personality characteristics intersect, personality and academic achievement may be directly related. As such, the purpose of the present study was to investigate the role of personality types of I/E, N/S, F/T, and P/J according to the MBTI taxonomy towards the learners' performance on the metaphor test which leads to better language and academic achievement and success. In fact, the aim was to have an investigation into the defining the role of personality types regarding metaphor test performance, and accordingly, to improve L2 learners' comprehension of metaphors.

Regarding the concerns of the present study, metaphorical expression as well as linguistic, and semantic elements include elements that concern human cognition and culture (Azuma, 2006). The cognitive approach viewed metaphor more as a matter of mind, or as Taki (2011) asserted, as a set of fixed mappings between two conceptual domains. In fact, metaphors were a more abstracted model than a mental model which helped individuals made more inferences than they would make from less abstract data (Nonaka, 1991). As Astley and Zammuto manifested in their work in 1992, the ambiguous language of metaphors provides a cue to the learner and let the rest to him or her to interpret the meaning.

Regarding the perceiving category of personality and its positive relationship with metaphorical competence, to the best of our knowledge, nothing could be more effective than the spontaneity and flexibility of a perceiving learner. According to Wolk and Nikoli (1997), an individual who prefered a perceiving category tend to follow a perceiving process in his or her behavior. The perceiving learners always welcome incoming and new information and prefer to see all sides of an issue. They are spontaneous, curious, flexible, and adaptable which may be the key to their good metaphorical comprehension.

The findings of this study could be useful to L2 pedagogy. During the last decade, individual learners had received a significant amount of attention as the central element in the complex process of learning an L2. According to McDonouch and Shaw (2003), an understanding of L2 learners' characteristics could prove helpful to L2 classrooms by adjusting certain aspects of the classroom. In this regard, the role of personality and personality types had also been mentioned as the most effective participant in life affairs and actions (Racicot et al., 2011). Because of the wide domain of L2 pedagogy, anything which could help L2 learners in better learning things was of paramount importance, so a significant amount of attention had been put on metaphor and its vital and indispensable used in everyday language in the last two decades (Feldman, 2006; Gibbs, 2006a, b, c; Lakoff, in press; Lakoff \& Johnson, 1999).

Metaphorical competence had been considered by many (e.g., Hashemian, 2007; Hashemian \& Talebinezhad, 2007) as a good tool for measuring L2 proficiency in L2 teaching (Hashemian, 2007; Littlemore \& Low, 2006). Because of the vital importance of metaphorical competence in L2 research, and its role and effect on better comprehending and learning of an L2 (Hashemian, 2007; Littlemore \& Low, 2006), the present study was set out to find out and to determine the role that personality type plays in this domain.

Subsequently, the findings of this study would help L2 teachers with a better understanding of L2 learners and help them made use of the detailed portfolios of L2 learners and finding their areas of weakness and strength and act accordingly by finding the best suited methodology, materials to be presented, activities, and means of assessment for those learners. 
Indonesian Journal of Learning and Instruction Volume 1, Issue 2, October 2018

It was worth mentioning that an increasing body of research suggested that personality was vital for success in many areas of life (Racicot et al., 2011). The present study attempted to detect the effect of different personality types-thinking/feeling and judging/perceiving- on L2 learners' metaphorical competence.

L2 learners with different personality types (e.g., extroversion vs. introversion) react differently to different teaching methods and materials presented by the teachers (Myers \& Myers, 1980; Tieger\& Barron-Tieger, 1995). L2 learners knew their personality types and their relation with metaphorical competence could try to do their best to improve these two related concepts so as to communicate better in L2 contexts, cultures, and societies. Almost none of the studies conducted so far (e.g., Azuma, 2005; Danesi, 1992; Hashemian, 2007; Hashemian \&Talebinezhad, 2007; Littlemore \& Low, 2006) had investigated the relationship between metaphorical competence and personality types; so, this study sought to fill the existing gap.

\section{CONCLUSION}

According to the results of the metaphor test, the feeling/thinking category of personality plays no significant role on the participants' metaphorical competence, whereas there is a significant difference in the scores of the perceiving and the judging participants. Thus, the difference between these two groups may be attributed to the personality type of the learners, in a way that the perceiving participants outperformed the judging ones on the metaphor test.

\section{REFERENCES}

Allen, D. (2004). The Oxford placement test. Oxford: Oxford University Press.

Aristotle. (1965). Poetics. Oxford: Blackwell.

Azuma, M. (2005). Metaphorical competence in an EFL context: The mental lexicon and metaphorical competence of Japanese EFL students. Tokyo: Toshindo Publishing.

Balkis, M., \& Isiker, G. B. (2005). The relationship between thinking styles and personality types.
p-ISSN 2614-8250, e-ISSN 2614-5677

https://journal.uniku.ac.id/index.php/IJLI

Social Behavior and Personality, 33(3), 283294.

Binet, A. (1905). A propos la mesure de l' intelligence. L' AnneePsychol, 2, 411-465.

Brown, H. D. (2000). Principles of language learning and teaching $\left(4^{\text {th }}\right.$ ed.). White Plains, New York: Addison Wesley Longman.

Caspi, A., Roberts, B. W., \& Shiner, R. L. (2005). Personality development: Stability and change. Annual Review of Psychology, 56, 453-484.

Collis, H. (2004). 136 American idioms. USA: NTC/Contemporary Publishing Group, INC.

Crookes, G., \& Schmidt, R. (1991). Motivation: Reopening the research agenda. Language Learning, 40, 45-78.

Danesi, M. (1992). Metaphorical competence in second language acquisition and second language teaching: The neglected dimension. In J. E. Alatis (Eds.), Georgetown University round table on language and linguistics (pp. 489-500). Washington, DC: Georgetown University Press.

Danesi, M. (1994). Recent research on metaphor and the teaching of Italian. Italica, 71, 453-464.

Danesi, M. (1995). Learning and teaching languages: The role of conceptual fluency. International Journal of Applied Linguistics, 5(1), 3-20.

Donglin, Q., \& Yin, C. (2009). A data-based investigation into Chinese EFL learners' metaphorical competence. Teaching English in China-CELEA Journal, 32(4), 96-103.

Erton, I. (2010). Relations between personality traits, language learning styles and success in foreign language achievement. H. U. Journal of Education, 38, 115-126.

Eysenck, H. J. (1997). Addiction, personality, and motivation. Journal of Human Pharmacology, 12, 79-87.

Eysenck, H. J., \& Eysenck, S. B. G. (1964). Manual of the Eysenck personality inventory. London: Hodder and Stoughton.

Feldman, G., (2006). From molecules to metaphor: A neural theory of language. Cambridge, MA: MIT Press.

Flege, J. E., Yeni-Komshian, G. H., \& Liu, S. (1999). Age constraints on second-language acquisition. Journal of Memory and Language, 41, 78-104.

Furnham, A. (1996). The big five versus the big four: The relationship between the Myers-Briggs Type Indicator (MBTI) and NEO-PI five factor model of personality. Personality and Individual Differences, 21(2), 303-307.

Furnham, A. C., Jackson, J., Forde, L., \& Cotter, T. (2001). Correlates of the Eysenck personality profile. Personality and Individual Differences, 30(4), 587-594.

Gardner, H. (1983). Frames of mind: The theory of multiple intelligences. New York: Basic Books. 


\section{Mahmood Hashemian}

A study of L2 learners' metaphorical competence and personality types: A case of thinking/feeling vs. judging/perceiving personality categories

Gardner, H., \& Winner, E. (1978). The development of metaphoric competence: Implications for humanistic disciplines. Critical Inquiry, 5(1), 123-141.

Gibbs, R. (2006a). Embodiment and cognitive science. NY: Cambridge University Press.

Gibbs, R. (2006b). The psychological status of image schemas. In H. Beate (Eds.), From perception to meaning: Image schemas in cognitive linguistics (pp. 113-136). Mouton de Gruyter, Berlin.

Gibbs, R. (2006c). Metaphor interpretation as embodied simulation. Mind \& Language, 21, 434-458.

Greathead, D. (2008). MBTI personality type and student code comprehension skills. Paper presented at the $20^{\text {th }}$ Annual Workshop in Lancaster, United Kingdom.

Hakimi, S., Hejazi, E., \& Lavasani, M. G. (2012). The relationship between personality traits and students' academic achievement. ProcediaSocial and Behavioral Sciences, 29, 836-845.

Halliday, M. A. k. (1985). An introduction to functional grammar. London: Edward Arnold.

Hashemian, M. (2007). Conceptual fluency and metaphorical competence in L2. Unpublished doctoral dissertation, University of Isfahan, Iran.

Hashemian, M., \& Talebinezhad, M. R. (2007). The development of conceptual fluency and metaphorical competence in L2 Learners. Linguistik Online, 27(1), 41-56.

Holland, J. L. (1973). Making vocational choices: A theory of careers. Englewood Cliffs, NJ: Prentice-Hall.

Honey, P., \& Mumford, A. (1992). The manual of learning style ( $3^{\text {rd }}$ ed.). Maidenhead: Peter Honey.

Hymes, D. H. (1966). Two types of linguistic relativity. In W. Bright (Eds.), Sociolinguistics (pp. 114-158). The Hague: Mouton.

Johnson, M. H. (1987). The body in the mind: The bodily basis of meaning, imagination, and reason. Chicago: University of Chicago Press.

Jung, C. G. (1976). Psychological types. Princeton, N.J.: Princeton University Press.

Keirsey, D., \& Bates, M. (1978). Please understand me-character and temperament types. Del Mar, CA: Prometheus Nemesis Book Company.

Kinnear, P. R., \& Gray, C. D. (1999). SPSS for Windows made simple ( $3^{\text {rd }}$ ed.). Hove, United Kingdom: Psychology Press Ltd.

Kövecses, Z. (2006). Metaphor in culture: Universality and variation. Journal of Pragmatics, 38, 1528-1531.

Lakoff, G. (in press). The neural theory of metaphor. In R. Gibbs (Eds.), Cambridge handbook of metaphor and thought (pp. 17-38). NY: Cambridge University Press.

Lakoff, G. (1987). Women, fire, and dangerous things. Chicago: University of Chicago Press.
Lakoff, G., \& Johnson, M. (1980). Metaphors we live by. Chicago: University of Chicago Press.

Lakoff, G., \& Johnson, M. (1999). Philosophy in the flesh. New York: Basic Books.

Lawrence, G. (1984). A synthesis of learning style research involving MBTI. Journal of Psychology, 8(2), 63-101.

Littlemore, J., \& Low, G. (2006). Metaphoric competence, second language learning, and communicative language ability. Applied Linguistics, 27(2), 268-294.

Marefat, F. (2006). Student writing, personality type of the student and the rater: Any interrelationship? Reading Matrix, 6(2), 116124.

McDonouch, J., \& Shaw, C. (2003). Materials and methods in ELT (2 $2^{\text {nd }}$ ed.). UK: Blackwell Publishing.

McGlone, M. S. (2007). What is the explanatory value of a conceptual metaphor? Language \& Communication, 27, 109-126.

Michalski, R. L., \& Shackelford, T. K. (2010). Evolutionary personality psychology: Reconciling human nature and individual differences. Journal of Personality and Individual Differences, 48, 509-516.

Myers, I. B., \& Myers, P. B. (1980). Gifts differing-Understanding personality type. Palo Alto, CA: Davies-Black Publishing.

Nonaka, I. (1991). The knowledge-creating company. Harvard Business Review, 69(6), 96-104.

Ortony, A. (1975). Why metaphors are necessary and not just nice. Educational Theory, 25(1), 45-53.

Pallant, J. (2007). SPSS survival manual. England: Open University Press.

Pittenger, D. J. (1993). Measuring the MBTI ... And coming up short. Journal of Career Planning \& Placement, 54(1), 48-52.

Pollio, H., Barlow, J., Fine, H., \& Pollio, M. (1977). The poetics of growth: Figurative language in psychology, psychotherapy, and education. Hillsdale, N.J.: Lawrence Erlbaum Associates.

Postman, N., \& Weingartner, C. (1969). Teaching as a subversive activity. NY: Dell.

Quenk, N. L. (1993). Beside ourselves-Our hidden personality in everyday life. Palo Alto, CA: Davies-Black Publishing.

Racicot, M., Venne, D., Durivage, A., \& Vaillancourt, J. P. (2011). Evaluation of the relationship between personality traits, experience, education, and biosecurity compliance on poultry farms in Quebec, Canada. Elsevier B. V., 10 (2\&3), 1-7.

Reid, J. M. (1987). The learning style preferences of ESL students. TESOL Quarterly, 21(1), 87-110.

Sacristan, M. V. (2004). Metaphor and ESP: Metaphor as a useful device for teaching L2 business English learners. IBÉRICA, 10, 115131. 
Indonesian Journal of Learning and Instruction Volume 1, Issue 2, October 2018

Saucier, G., \& Goldberg, L. R. (2003). The structure of personality attributes. In M. R. Barrick, \& A. M. Ryan (Eds.), Personality and work: Reconsidering the role of personality in organizations (pp. 1-29). San Francisco: Jossey Bass.

Smith, A. B., Irey, R. K., \& McCaulley, M. H. (1973). Self-paced instruction and college student personalities. Engineering Education, 43(6), 435-440.

Taki, S. (2011). Cross-cultural communication and metaphorical competence. International Journal of Language Studies, 5(1), 47-62.

Teepen, J. (2005). On the relationship between aptitude and intelligence in second language acquisition. TESOL \& Applied Linguistics, 4(3), 1-9.

Tendahl, M., \& Gibbs, R. W., Jr. (2008). Complementary perspectives on metaphor: Cognitive linguistics and relevance theory. Journal of Pragmatics, 30, 1-42.

Tieger, P. D., \& Barron-Tieger, B. (1995). Do what you Are-Discover the perfect career for you through the secrets of personality type ( $2^{\text {nd }} \mathrm{ed}$.). New York, NY: Little, Brown and Company.

Tittle, M. (2000). Foreign language students' irrational beliefs, language anxiety, and classroom achievement. In O. Kagan \& B. Rifkin (Eds.), The learning and teaching of
p-ISSN 2614-8250, e-ISSN 2614-5677

https://journal.uniku.ac.id/index.php/IJLI

Slavic languages and cultures: Toward the $21^{\text {st }}$ century (pp. 167-192). Bloomington, IN: Slavica.

Wankat, P. C., \& Oreovicz, F. S. (2002). The scholarship of teaching and learning engineering. In Huber \& S. Morreale (Eds.), Disciplinary styles in the scholarship of teaching and learning: Exploring common ground (pp. 244-269). Washington: AAHE/Carnegie Foundation for the Advancement of Teaching.

Wilz, B. (2000). Relationship between personality type and grade point average of technical college students. Unpublished master's thesis, University of Wisconsin-Stout, Menomonie, WI.

Wolk, C., \& Nicoli, L. A. (1997). Personality types of accounting students and faculty: Comparisons and implications. Journal of Accounting Education, 15(1), 1-17.

Wright, J. (1999). Idioms organiser: Organized by metaphor, topic, and key word. UK: Thomson Heinle.

Yan, L. V. (2007). The development of metaphorical competence in EFL learners: A case study. Unpublished master's thesis, Donghua University, College of Foreign Languages. 